\title{
World Food Safety Day: In the Midst of the Pandemic
}

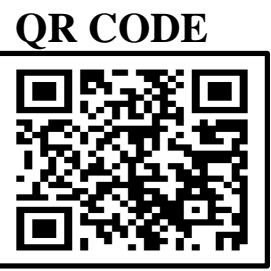

\section{MANSIMRANIIT KAUR UPPAL ${ }^{\text {iD }}$}

The World Food Safety Day (WFSD) is celebrated on the seventh day of June every year. Its primary aim is to draw attention and inspiring actions that help prevent, detect and manage foodborne risks, contribute to food security, human health, economic prosperity, agriculture, market access, tourism and sustainable development. The theme for the year 2021 is aptly chosen as "Safe food today for a healthy tomorrow"

This day was first celebrated in the year 2018 by the WHO and the Food and Agriculture Organization of the United Nations (FAO) in collaboration with member states and other relevant organizations.

As I was going through materials on food safety to write this editorial, I stumbled upon a video by the WHO which stated that "Food safety is everyone's business" and support the statement. The safety of our food is a shared responsibility between governments, producers, as well as the consumers. In this editorial, I would like to share a few thoughts with consumers regarding food safety.

When the World Health Organization (WHO) declared the COVID-19 outbreak as a Public Health Emergency of International Concern on $30^{\text {th }}$ January 2020, and a pandemic on $11^{\text {th }}$ March 2020, ${ }^{1}$ it was time for governments and people to swing into preventive action. Governments starting enforcing lockdowns and people were limited to the comfort of their homes and the world was brought to a standstill. As a precautionary measure, people started paying proper attention to materials bought to their homes. People were sanitizing their laptops, smartphones, clothes, etc. Food items, especially vegetables were being washed in soap, bleach, sanitizers and detergent before being consumed and was supported by false, misleading statements by various people. ${ }^{3}$

The public should be advised that soap and detergent is meant for crockery and not for washing vegetables. The biggest risk in doing so is the possibility of getting exposed to other contaminants and subsequent poisoning. Scientists have stated that the virus is fragile in nature and while most fruits and vegetables are peeled and boiled during the cooking process, thereby killing the virus, fruits like apple can be simply washed under running water before consumption.

There is no evidence from the WHO and other agencies that state that food is a vehicle for the virus and hence, unsafe. The CDC further clarifies that the risk of getting COVID-19 from food cooked at home or from handling and consuming food from restaurants and takeout or drive-thru meals is thought to be very low; and hence, most countries have allowed either take away and dine-in or both. ${ }^{4}$

In the case of a food delivery, one can reduce the risk of packaging contamination simply by just emptying the contents into a clean dish, followed by proper disposal of the packaging into a refuse bag and washing hands immediately thereafter. I advise the readers to take food out of a container with a spoon and eat it with a knife and fork - and not one's hands. Given the present circumstances, it is better to only order hot, freshly cooked food and avoid cold or raw items (although if handled properly, the risk of contamination remains low). It is also advisable to reheat the food for a couple of seconds in the microwave before consumption. 5

With the world battling the brutal onslaught of the virus, vaccinations are helping people in bringing the world slowly and gradually to pre-pandemic levels. I request all hesitant people to get themselves vaccinated as well as practice safe social distancing norms as the fight is not over but slowly and gradually, we are inching towards defeating this virus.

\section{REFERENCES}

1. WHO. World Food Safety Day 2021 (Online Article). Available from: https://www.who.int/news- 
room/campaigns/world-food-safety-

day/2021\#: :text=Safe\%2ofood\%2onow\%2ofor\%20a\% zohealthy\%2otomorrowEtext=This\%2oyear's\%2othe me\%2C\%20'Safe\%2ofood, the\%2oplanet\%2oand\%2oth e\%20economy.Etext $=$ Food\%20safety\%2ois\%2oeveryo ne's\%2obusiness. [Last Accessed on ${ }_{12}{ }^{\text {th }}$ May, 2021] 2. WHO. WHO Director-General's opening remarks at the media briefing on COVID-19 - 11 March 2020 (Online Article). Available from: https://www.who.int/directorgeneral/speeches/detail/who-director-general-sopening-remarks-at-the-media-briefing-on-covid-19--11-march-2020. [Last Accessed on $12^{\text {th }}$ May, 2021] 3. Neo P. 'Misleading advice': Poisoning risk of disinfecting fresh produce to prevent COVID-19 industry expert (Online Article). Available from: https://www.foodnavigator-

asia.com/Article/2020/04/27/Misleading-advicePoisoning-risk-of-disinfecting-fresh-produce-toprevent-COVID-19-industry-expert\#. [Last Accessed on $12^{\text {th }}$ May, 2021]

4.CDC. Food and Coronavirus Disease 2019 (COVID19). $\quad$ https://www.cdc.gov/coronavirus/2019ncov/daily-life-coping/food-and-COVID-19.html. 5. Gill V. BBC News. Coronavirus: How safe are takeaways and supermarket deliveries? (Online Article). Available from: https://www.bbc.com/news/science-environment52040138 [Last Accessed on $13^{\text {th }}$ May, 2021]

Cite this article as:

Uppal MK. World Food Safety Day: In the Midst of the Pandemic. Int Healthc Res J. 2021;5(2):GC1-GC2. https://doi.org/10.26440/IHRJ/0502.05420

\section{AUTHOR AFFILIATIONS:}

